\title{
The Precapillary Segment of the Blood- Brain Barrier and Its Relation to Perivascular Drainage in Alzheimer's Disease and Small Vessel Disease
}

\author{
Dietmar R. Thal \\ Institute of Pathology - Laboratory of Neuropathology, University of UIm, Germany \\ E-mail: Dietmar.Thal@uni-ulm.de
}

Received May 11, 2009; Revised June 9, 2009; Accepted June 10, 2009; Published July 4, 2009

\begin{abstract}
The blood-brain barrier (BBB) is the border between the brain tissue and the blood, and consists of a pre- and postcapillary segment, and a capillary segment. At the capillaries, protein transport is possible via receptor-mediated endocytosis through endothelial cells. At the arteries and veins, the BBB is thicker and there is, under physiological conditions, no direct transport from the brain tissue to the blood or vice versa. Here, extracellular fluid is drained into the perivascular space, which is a fluid-filled space between the border of the brain tissue, the glia limitans, and that of the vessel wall, the adventitia, as well as along basement membranes within the vessel wall. In the event of degenerative changes in the arterial vessel wall, known as small vessel disease (SVD), leakage of plasma proteins into the vessel wall and into the perivascular space occurs. Thus, the precapillary segment of the BBB is altered and drainage of extracellular fluid from the brain tissue competes with the leaking plasma for perivascular drainage. Since the amyloid $\beta$-protein $(A \beta)$ is subject to this perivascular drainage and accumulates in the brains of Alzheimer's disease (AD) patients, an alteration of this drainage system in the course of SVD may support the accumulation of $A \beta$ within the brain and, in so doing, the development of AD.
\end{abstract}

KEYWORDS: blood-brain barrier, perivascular space, apolipoprotein E, small vessel disease, Alzheimer's disease

\section{INTRODUCTION}

Perivascular drainage of the extracellular fluid of the brain is one of the clearance mechanisms for proteins in the brain[1]. Other clearance mechanisms are cellular uptake with subsequent lysosomal degradation or transport through the capillary segment of the blood-brain barrier (BBB) as described, for example, for the amyloid $\beta$-protein $(\mathrm{A} \beta)[2,3,4,5,6,7,8,9]$.

The morphological correlatives for perivascular drainage of interstitial fluid are the perivascular spaces[1] and the basement membranes within the vessel walls[10,11]. Proteins that are produced in the brain are cleared into the perivascular space[12]. The perivascular fluid is further drained either into the cerebrospinal fluid (CSF) or into cervical lymph nodes[1]. Thus, this drainage mechanism is mainly 
located in the noncapillary segments of the BBB and seems to be involved in the pathogenesis of brain diseases, such as Alzheimer's disease $(\mathrm{AD})$ or neuroinflammatory disorders[1,2,11]. Under normal conditions, pericytes control the postendothelial permeability of the BBB to the perivascular space, especially in the pre- and postcapillary segment[2]. The glia limitans represents a barrier between the brain parenchyma and the perivascular space[2].

This review is focused on the precapillary segment of the BBB and describes its anatomy, function in protein clearance, and its relation to $\mathrm{AD}$ and small vessel disease (SVD). A possible pathogenetic role of alterations in the precapillary segment of the BBB and the perivascular drainage for the development of $\mathrm{AD}$ is discussed.

\section{ANATOMY OF THE BBB AND ITS RELATION TO PERIVASCULAR DRAINAGE}

The morphological correlatives of perivascular drainage channels are the perivascular spaces in the preand postcapillary segments of the BBB, and the basement membranes in all segments of the BBB (Fig. 1) $[11,12,13]$. The perivascular space is usually bordered by the glia limitans of the brain and adventitial pericytes[2] (Fig. 1). In larger vessels of the basal ganglia, the glia limitans and the adventitia are covered by a thin layer of the pia mater in contrast to smaller brain vessels[14]. In comparison to the BBB capillary segment consisting of the endothelium, the basement membrane with pericytes, a minimal perivascular space, and the glia limitans, the vessels of the pre- and postcapillary segment have a lamina media and a significant adventitia in the vessel wall and larger perivascular spaces[2] (Fig. 1). At the capillary segment, the endothelium has the major barrier function and regulates fluid and protein transport $[2,15,16,17,18]$. The blood pressure in the capillaries is very low and the endothelial cell layer is usually not altered by the blood pressure. In the precapillary segment, on the other hand, the blood pressure is relatively high because these vessels are arteries or arterioles (Fig. 1). Therefore, a pressurerelated, mechanical alteration of the endothelial cell layer is possible, leading to the leakage of blood plasma into the vessel wall as similarly described as the first step in the pathogenesis of atherosclerosis[19]. In so doing, the lamina media and adventitia, the perivascular space, as well as the glia limitans, become more important for the efficiency of BBB function in the precapillary segment. The postcapillary segment can be altered in the course of inflammatory disorders, e.g., perivenous encephalomyelitis (= acute disseminated encephalomyelitis).

\section{PERIVASCULAR CLEARANCE OF A $\beta$ AND APOE IN THE NORMAL BRAIN}

Extracellular fluid in the brain is drained from the brain parenchyma either into the CSF or into perivascular channels, finally ending at the cervical lymph nodes[1]. Thus, proteins in the extracellular space are also subject to perivascular clearance, including $A \beta$ (a protein that accumulates in the brains of $\mathrm{AD}$ patients in the form of extracellular senile plaques) and apolipoprotein $\mathrm{E}$ (apoE, a protein that is involved in lipid and $A \beta$ transport; the APOE $\varepsilon 4$ allele is a risk allele for $A D)$ ). For $A \beta$ as well as for apoE, it could be shown that the proteins produced by astrocytes (apoE) or neurons $(A \beta)$ occur in the perivascular space of transgenic mice expressing a human-specific form of apoE in astrocytes[12], or producing $A \beta$ due to an overexpression of neuronal amyloid precursor protein (APP)[20]. Under normal conditions, significant amounts of apoE can be detected in the perivascular space, whereas only low levels of $\mathrm{A} \beta$ were detectable in wild-type mice as well as in nondemented human autopsy cases[12,21]. Moreover apoE receptors, such as the $\alpha_{2}$ macroglobulin receptor/low-density lipoprotein receptor-related protein (LRP1), are expressed in glial cells and along the BBB, and take up apoE-linked $\mathrm{A} \beta[3,5,22,23,24,25,26]$. Therefore, it is tempting to speculate that apoE is physiologically involved in transport and/or clearance mechanisms for, for example, lipids and $A \beta$ through the perivascular space. 
Extracranial lymph nodes

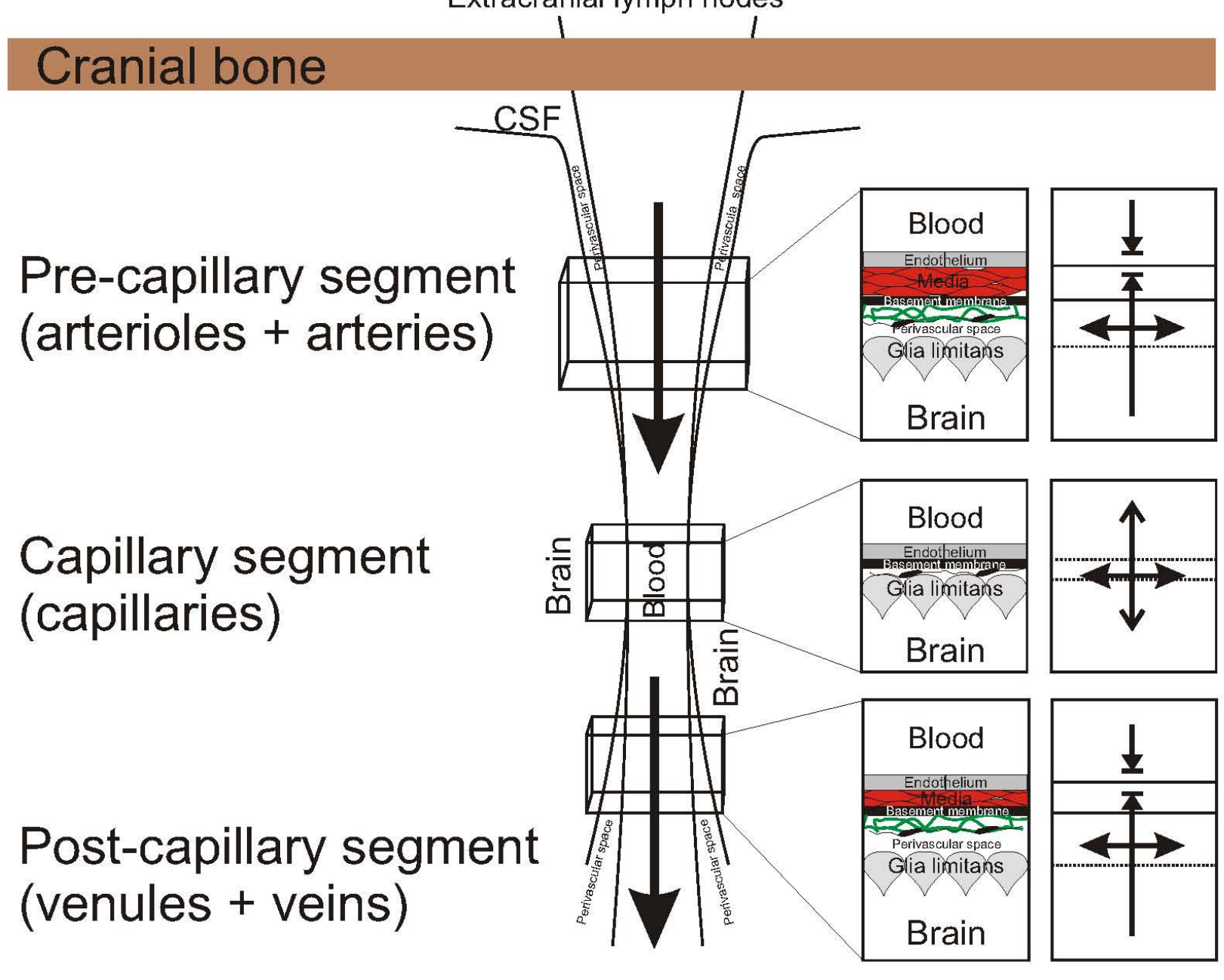

Topography

Histology BBB-function

FIGURE 1. Schematic representation of the three segments of the BBB. Topographically, the precapillary segment of the BBB is associated with the intracerebral arteries and arterioles, whereas the postcapillary segment is associated with intracerebral venules and veins. The capillary BBB segment represents all capillaries of the brain parenchyma. Arteries and veins enter the brain from the extracranial site. As demonstrated in the schematic representation of the histology, the perivascular space is significant in the pre- and postcapillary segment, whereas it is negligible in the capillary one. Functionally, the endothelium of the pre- and postcapillary segments does not allow significant transport of fluid or proteins from the blood into the perivascular space and the brain parenchyma, or vice versa. Even the high arterial blood pressure in the precapillary segment does not lead to plasma leakage under normal conditions. However, extracellular fluid and proteins can be cleared into the perivascular space and into vascular basement membranes from where it is drained into the CSF or to the extracranial cervical lymph nodes $[1,10]$.

\section{PERIVASCULAR CLEARANCE OF A $\beta$ AND APOE IN THE AGED AND THE AD BRAIN, AND ITS RELATION TO CEREBRAL SVD}

Since apoE and $\mathrm{A} \beta$ are cleared through the perivascular space and possibly through the vessel walls along the basement membranes, it should be expected that perivascular drainage receives relevance for diseases in which one or both of these proteins are involved. Two of such diseases are AD and cerebral SVD (i.e., a degenerative disorder of small arteries and arterioles). A $\beta$ is the major protein component of senile plaques in $\mathrm{AD}[27]$ and the APOE $\varepsilon 4$ allele is the major risk factor for sporadic $\mathrm{AD}[28]$. In $\mathrm{SVD}$, apoE is found in vessel wall lesions[21] and its $\varepsilon 4$ allele is associated with the severity of the disease[29]. 
Alterations of the perivascular drainage of $\mathrm{A} \beta$ are found in $\mathrm{AD}$ as indicated by the findings that (1) $\mathrm{A} \beta$ is cleared through the perivascular space[1] in addition to its cellular uptake and degradation[4,6,8,30], and its clearance across the capillary BBB segment[25,31,32]; (2) cerebral amyloid angiopathy (i.e., the deposition of $A \beta$ in the vessel wall near the basement membrane[33] and the perivascular space) occurs, strongly suggesting that $A \beta$ clearance along the basement membranes and the perivascular spaces is insufficient in $\mathrm{AD}$ cases and, thereby, leads to the deposition of $\mathrm{A} \beta$ in the vessel walls[11,12,13,20]; and (3) apoE colocalizes with $A \beta$ in the perivascular space[12,21], indicating that the interaction between $A \beta$ and apoE is relevant for perivascular drainage. Therefore, differences in the $A \beta$ apoE interactions due to the APOE genotype[34] may modify the efficiency of this drainage pathway for $\mathrm{A} \beta$ and subsequently lead to the development of $\mathrm{AD}$-related changes in the brain. The astrocytes of the glia limitans, thereby, appear to play an important role for the clearance mechanism. In an animal model expressing human apoE in astrocytes, glia limitans astrocytes exhibited human apoE and secreted it into the perivascular space[12]. In the human $\mathrm{AD}$ brain, these perivascular apoE-expressing astrocytes also contained $\mathrm{A} \beta[21]$, whereas non-AD cases showed $\mathrm{A} \beta$-negative perivascular astrocytes most frequently[21]. Thus, the glia limitans function seems to be altered in AD.

In SVD, apoE is found in lesions of the vessel wall[21]. These lesions do not only contain apoE, but also other plasma proteins, such as immunoglobulin $\mathrm{G}$ (IgG), indicating leakage of plasma proteins into the vessel wall and, in most cases with SVD, also into the perivascular space[21]. Thus, SVD, which is often associated with hypertension[35], leads to a leakage of plasma proteins into the perivascular space caused by a mechanical alteration of the BBB precapillary segment (Fig. 2). Additionally, hypertension leads to an increased pinocytosis in endothelial cells of the arteriolar segment[36] and to a leakage of plasma proteins into the brain[37], pointing to an increased plasma transport through endothelial cells in hypertension.

\section{A Normal}
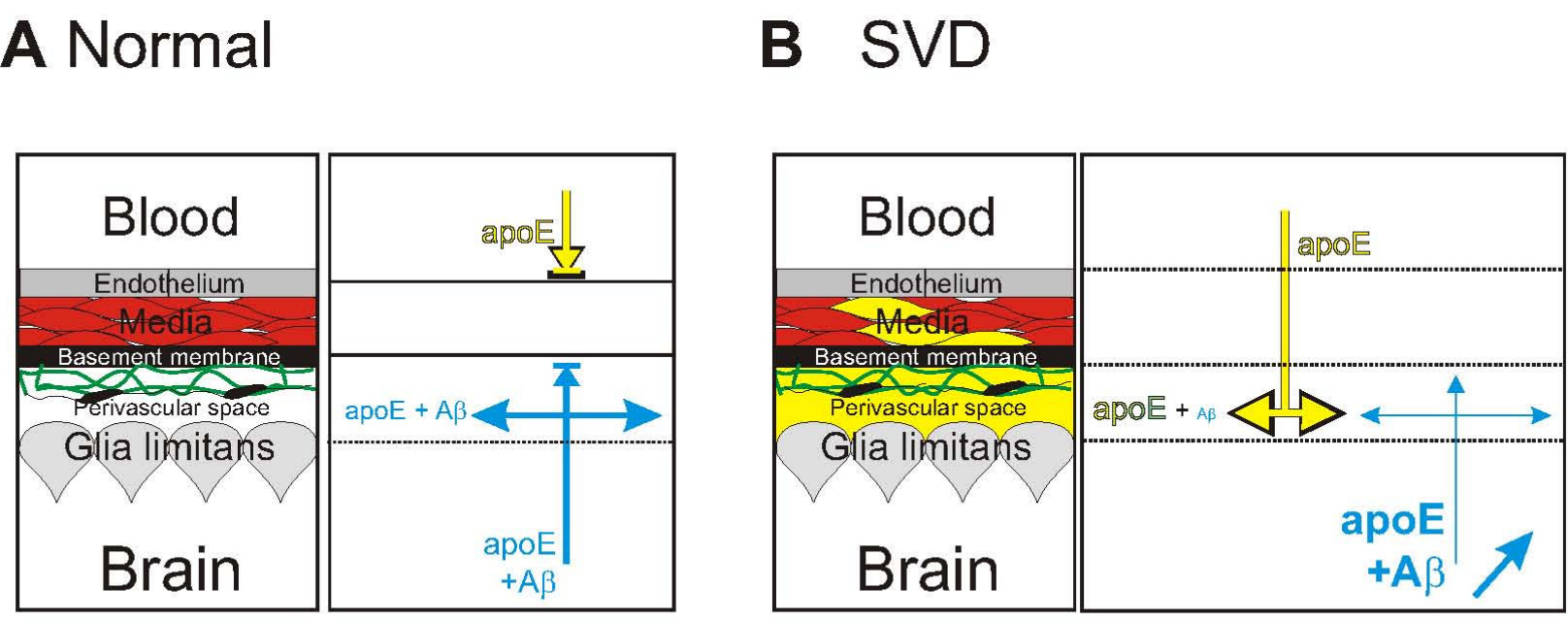

FIGURE 2. Schematic representation of the SVD-induced alteration of the precapillary segment of the BBB. (A) Physiological situation. (B) SVD-related BBB alteration. Due to endothelial lesions and the high arterial blood pressure, plasma leaks into the media of the arteries and finally into the perivascular space. Here, plasma proteins, including apoE, compete with the extracellular fluid, including brain-derived apoE and $\mathrm{A} \beta$, for drainage. This competition leads to an insufficient clearance of brain apoE and $A \beta$, and finally to the accumulation of $A \beta$ in the brain and the predominance of apoE-cleavage fragments in relation to full-length apoE[21].

Since SVD and its expansion throughout the brain, as well as the expansion of SVD-related MRI hyperintensities, are associated with the development of $\mathrm{AD}[38,39,40]$, the involvement of alterations in the perivascular drainage in both disorders may point to a pathogenetic link between both disorders. Hence, apoE may play an important role, since the clearance of apoE-bound $A \beta$ from the brain 
parenchyma will be reduced in the event that plasma containing apoE leaks into the perivascular space and competes for the perivascular drainage (Fig. 2). Such a competitive inhibition of $A \beta$ clearance into the perivascular space and into the CSF may explain the well-known decrease of A $\beta$ in the CSF of AD patients[41,42].

\section{CONCLUSIONS}

The pre- and postcapillary segments of the BBB are usually not significantly involved in the physiological exchange mechanisms between the brain parenchyma and the blood. However, the perivascular spaces and the vascular basement membranes allow the drainage of extracellular fluid and proteins from the brain into the CSF and the cervical lymph nodes[1,10]. The glia limitans, thereby, represents the border between the brain parenchyma and the perivascular fluid (Fig. 1). In the event that vessel disorders or inflammation cause a leakage of plasma into the perivascular space (e.g., SVD in the precapillary segment; encephalomyelitis disseminata in the postcapillary segment), the BBB is altered although the capillary segment may still be intact. Although there may be no direct influx of blood plasma into the brain parenchyma, the plasma with its proteins competes with the extracellular fluid for the perivascular drainage pathway that is usually reserved for the brain extracellular fluid (Fig. 2). In so doing, the drainage capacity for brain extracellular fluid and proteins could be reduced, leading (for example, in sporadic $A D$ ) to the retention of $A \beta$ and apoE in the brain, triggering the cascade of $A D-$ related neurodegeneration (Fig. 2).

Thus, alterations of the precapillary segment of the BBB seem to play an important role in the development of sporadic AD. SVD is, thereby, one important possible cause for precapillary BBB alterations.

\section{ACKNOWLEDGMENTS}

Parts of the work, reviewed here, were supported by the DFG (grant Nos. TH624/4-1, TH624/4-2). The author thanks Dr. E. Ghebremedhin for critical reading of the manuscript.

\section{REFERENCES}

1. Weller, R.O. (1998) Pathology of cerebrospinal fluid and interstitial fluid of the CNS: significance for Alzheimer disease, prion disorders and multiple sclerosis. J. Neuropathol. Exp. Neurol. 57, 885-894.

2. Bechmann, I., Galea, I., and Perry, V.H. (2007) What is the blood-brain barrier (not)? Trends Immunol. 28, 5-11.

3. Zlokovic, B.V. (2008) The blood-brain barrier in health and chronic neurodegenerative disorders. Neuron 57, 178201.

4. Iwata, N., Tsubuki, S., Takaki, Y., Watanabe, K., Sekiguchi, M., Hosoki, E., Kawashima-Morishima, M., Lee, H.J., Hama, E., Sekine-Aizawa, Y., and Saido, T.C. (2000) Identification of the major Abeta1-42-degrading catabolic pathway in brain parenchyma: suppression leads to biochemical and pathological deposition. Nat. Med. 6, 143-150.

5. Koistinaho, M., Lin, S., Wu, X., Esterman, M., Koger, D., Hanson, J., Higgs, R., Liu, F., Malkani, S., Bales, K.R., and Paul, S.M. (2004) Apolipoprotein E promotes astrocyte colocalization and degradation of deposited amyloid-beta peptides. Nat. Med. 10, 719-726.

6. Schenk, D., Barbour, R., Dunn, W., Gordon, G., Grajeda, H., Guido, T., Hu, K., Huang, J., Johnson-Wood, K., Khan, K., Kholodenko, D., Lee, M., Liao, Z., Lieberburg, I., Motter, R., Mutter, L., Soriano, F., Shopp, G., Vasquez, N., Vandevert, C., Walker, S., Wogulis, M., Yednock, T., Games, D., and Seubert, P. (1999) Immunization with amyloidbeta attenuates Alzheimer-disease-like pathology in the PDAPP mouse. Nature 400, 173-177.

7. Wyss-Coray, T., Loike, J.D., Brionne, T.C., Lu, E., Anankov, R., Yan, F., Silverstein, S.C., and Husemann, J. (2003) Adult mouse astrocytes degrade amyloid-beta in vitro and in situ. Nat. Med. 9, 453-457.

8. Akiyama, H., Schwab, C., Kondo, H., Mori, H., Kametani, F., Ikeda, K., and McGeer, P.L. (1996) Granules in glial cells of patients with Alzheimer's disease are immunopositive for C-terminal sequences of beta-amyloid protein. Neurosci. Lett. 206, 169-172. 
9. Miller, B.C., Eckman, E.A., Sambamurti, K., Dobbs, N., Chow, K.M., Eckman, C.B., Hersh, L.B., and Thiele, D.L. (2003) Amyloid-beta peptide levels in brain are inversely correlated with insulysin activity levels in vivo. Proc. Natl. Acad. Sci. U. S. A. 100, 6221-6226.

10. Carare, R.O., Bernardes-Silva, M., Newman, T.A., Page, A.M., Nicoll, J.A., Perry, V.H., and Weller, R.O. (2008) Solutes, but not cells, drain from the brain parenchyma along basement membranes of capillaries and arteries: significance for cerebral amyloid angiopathy and neuroimmunology. Neuropathol. Appl. Neurobiol. 34, $131-144$.

11. Weller, R.O., Djuanda, E., Yow, H.Y., and Carare, R.O. (2009) Lymphatic drainage of the brain and the pathophysiology of neurological disease. Acta Neuropathol. 117, 1-14.

12. Thal, D.R., Larionov, S., Abramowski, D., Wiederhold, K.H., Van Dooren, T., Yamaguchi, H., Haass, C., Van Leuven, F., Staufenbiel, M., and Capetillo-Zarate, E. (2007) Occurrence and co-localization of amyloid beta-protein and apolipoprotein E in perivascular drainage channels of wild-type and APP-transgenic mice. Neurobiol. Aging 28, 1221-1230.

13. Weller, R.O., Massey, A., Newman, T.A., Hutchings, M., Kuo, Y.M., and Roher, A.E. (1998) Cerebral amyloid angiopathy: amyloid beta accumulates in putative interstitial fluid drainage pathways in Alzheimer's disease. Am. $J$. Pathol. 153, 725-733.

14. Pollock, H., Hutchings, M., Weller, R.O., and Zhang, E.T. (1997) Perivascular spaces in the basal ganglia of the human brain: their relationship to lacunes. J. Anat. 191(Pt 3), 337-346.

15. Laterra, J. and Goldstein, G.W. (2000) Ventricular organization of cerebrospinal fluid: blood-brain barrier, brain edema, and hydrocephalus. In Principles of Neural Science. Kandel, E.R., Schwartz, J.H., and Jessell, T.M., Eds. McGraw-Hill, New York. pp. 1288-1301.

16. Wolburg, H., Noell, S., Mack, A., Wolburg-Buchholz, K., and Fallier-Becker, P. (2009) Brain endothelial cells and the glio-vascular complex. Cell Tissue Res. 335, 75-96.

17. Moody, D.M. (2006) The blood-brain barrier and blood-cerebral spinal fluid barrier. Semin. Cardiothorac. Vasc. Anesth. 10, 128-131.

18. Abbott, N.J., Ronnback, L., and Hansson, E. (2006) Astrocyte-endothelial interactions at the blood-brain barrier. Nat. Rev. Neurosci. 7, 41-53.

19. Stary, H.C., Chandler, A.B., Glagov, S., Guyton, J.R., Insull, W., Jr., Rosenfeld, M.E., Schaffer, S.A., Schwartz, C.J., Wagner, W.D., and Wissler, R.W. (1994) A definition of initial, fatty streak, and intermediate lesions of atherosclerosis. A report from the Committee on Vascular Lesions of the Council on Arteriosclerosis, American Heart Association. Circulation 89, 2462-2478.

20. Calhoun, M.E., Burgermeister, P., Phinney, A.L., Stalder, M., Tolnay, M., Wiederhold, K.H., Abramowski, D., Sturchler-Pierrat, C., Sommer, B., Staufenbiel, M., and Jucker, M. (1999) Neuronal overexpression of mutant amyloid precursor protein results in prominent deposition of cerebrovascular amyloid. Proc. Natl. Acad. Sci. U. S. A. 96, $14088-14093$.

21. Utter, S., Tamboli, I.Y., Walter, J., Rijal Upadhaya, A., Birkenmeier, G., Pietrzik, C.U., Ghebremedhin, E., and Thal, D.R. (2008) Cerebral small vessel disease-induced apolipoprotein E leakage is associated with Alzheimer disease and the accumulation of amyloid beta-protein in perivascular astrocytes. J. Neuropathol. Exp. Neurol. 67, 842-856.

22. Sagare, A., Deane, R., Bell, R.D., Johnson, B., Hamm, K., Pendu, R., Marky, A., Lenting, P.J., Wu, Z., Zarcone, T., Goate, A., Mayo, K., Perlmutter, D., Coma, M., Zhong, Z., and Zlokovic, B.V. (2007) Clearance of amyloid-beta by circulating lipoprotein receptors. Nat. Med. 13, 1029-1031.

23. Thal, D.R., Schober, R., and Birkenmeier, G. (1997) The subunits of alpha2-macroglobulin receptor/low density lipoprotein receptor-related protein, native and transformed alpha2-macroglobulin and interleukin 6 in Alzheimer's disease. Brain Res. 777, 223-227.

24. Bu, G. (2009) Apolipoprotein E and its receptors in Alzheimer's disease: pathways, pathogenesis and therapy. Nat. Rev. Neurosci. 10, 333-344.

25. Shibata, M., Yamada, S., Kumar, S.R., Calero, M., Bading, J., Frangione, B., Holtzman, D.M., Miller, C.A., Strickland, D.K., Ghiso, J., and Zlokovic, B.V. (2000) Clearance of Alzheimer's amyloid-ss(1-40) peptide from brain by LDL receptor-related protein-1 at the blood-brain barrier. J. Clin. Invest. 106, 1489-1499.

26. Yepes, M., Sandkvist, M., Moore, E.G., Bugge, T.H., Strickland, D.K., and Lawrence, D.A. (2003) Tissue-type plasminogen activator induces opening of the blood-brain barrier via the LDL receptor-related protein. J. Clin. Invest. 112, 1533-1540.

27. Masters, C.L., Simms, G., Weinman, N.A., Multhaup, G., McDonald, B.L., and Beyreuther, K. (1985) Amyloid plaque core protein in Alzheimer disease and Down syndrome. Proc. Natl. Acad. Sci. U. S. A. 82, 4245-4249.

28. Corder, E.H., Saunders, A.M., Strittmatter, W.J., Schmechel, D.E., Gaskell, P.C., Small, G.W., Roses, A.D., Haines, J.L., and Pericak-Vance, M.A. (1993) Gene dose of apolipoprotein E type 4 allele and the risk of Alzheimer's disease in late onset families. Science 261, 921-923.

29. Yip, A.G., McKee, A.C., Green, R.C., Wells, J., Young, H., Cupples, L.A., and Farrer, L.A. (2005) APOE, vascular pathology, and the AD brain. Neurology 65, 259-265.

30. Qiu, W.Q., Walsh, D.M., Ye, Z., Vekrellis, K., Zhang, J., Podlisny, M.B., Rosner, M.R., Safavi, A., Hersh, L.B., and Selkoe, D.J. (1998) Insulin-degrading enzyme regulates extracellular levels of amyloid beta-protein by degradation. $J$. Biol. Chem. 273, 32730-32738. 
31. Bell, R.D. and Zlokovic, B.V. (2009) Neurovascular mechanisms and blood-brain barrier disorder in Alzheimer's disease. Acta Neuropathol. 118(1), 103-113.

32. Kandimalla, K.K., Scott, O.G., Fulzele, S., Davidson, M.W., and Poduslo, J.F. (2009) Mechanism of neuronal versus endothelial cell uptake of Alzheimer's disease amyloid beta protein. PLOS ONE 4, e4627.

33. Yamaguchi, H., Yamazaki, T., Lemere, C.A., Frosch, M.P., and Selkoe, D.J. (1992) Beta amyloid is focally deposited within the outer basement membrane in the amyloid angiopathy of Alzheimer's disease. An immunoelectron microscopic study. Am. J. Pathol. 141, 249-259.

34. Deane, R., Sagare, A., Hamm, K., Parisi, M., Lane, S., Finn, M.B., Holtzman, D.M., and Zlokovic, B.V. (2008) apoE isoform-specific disruption of amyloid beta peptide clearance from mouse brain. J. Clin. Invest. 118, 4002-4013.

35. Lammie, G.A. (2002) Hypertensive cerebral small vessel disease and stroke. Brain Pathol. 12, 358-370.

36. Nag, S., Robertson, D.M., and Dinsdale, H.B. (1980) Morphological changes in spontaneously hypertensive rats. Acta Neuropathol. 52, 27-34.

37. Nag, S. (1996) Immunohistochemical localization of extracellular matrix proteins in cerebral vessels in chronic hypertension. J. Neuropathol. Exp. Neurol. 55, 381-388.

38. Brun, A. and Englund, E. (1986) A white matter disorder in dementia of the Alzheimer type: a pathoanatomical study. Ann. Neurol. 19, 253-262.

39. Thal, D.R., Ghebremedhin, E., Orantes, M., and Wiestler, O.D. (2003) Vascular pathology in Alzheimer's disease: correlation of cerebral amyloid angiopathy and arteriosclerosis/lipohyalinosis with cognitive decline. J. Neuropathol. Exp. Neurol. 62, 1287-1301.

40. Gouw, A.A., Seewann, A., Vrenken, H., van der Flier, W.M., Rozemuller, J.M., Barkhof, F., Scheltens, P., and Geurts, J.J. (2008) Heterogeneity of white matter hyperintensities in Alzheimer's disease: post-mortem quantitative MRI and neuropathology. Brain 131, 3286-3298.

41. Galasko, D., Chang, L., Motter, R., Clark, C.M., Kaye, J., Knopman, D., Thomas, R., Kholodenko, D., Schenk, D., Lieberburg, I., Miller, B., Green, R., Basherad, R., Kertiles, L., Boss, M.A., and Seubert, P. (1998) High cerebrospinal fluid tau and low amyloid beta42 levels in the clinical diagnosis of Alzheimer disease and relation to apolipoprotein $\mathrm{E}$ genotype. Arch. Neurol. 55, 937-945.

42. Kanai, M., Matsubara, E., Isoe, K., Urakami, K., Nakashima, K., Arai, H., Sasaki, H., Abe, K., Iwatsubo, T., Kosaka, T., Watanabe, M., Tomidokoro, Y., Shizuka, M., Mizushima, K., Nakamura, T., Igeta, Y., Ikeda, Y., Amari, M., Kawarabayashi, T., Ishiguro, K., Harigaya, Y., Wakabayashi, K., Okamoto, K., Hirai, S., and Shoji, M. (1998) Longitudinal study of cerebrospinal fluid levels of tau, A beta1-40, and A beta1-42(43) in Alzheimer's disease: a study in Japan. Ann. Neurol. 44, 17-26.

\section{This article should be cited as follows:}

Thal, D.R. (2009) The precapillary segment of the blood-brain barrier and its relation to perivascular drainage in Alzheimer's disease and small vessel disease. TheScientificWorldJOURNAL 9, 557-563. DOI 10.1100/tsw.2009.72. 


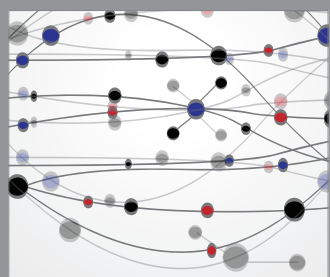

The Scientific World Journal
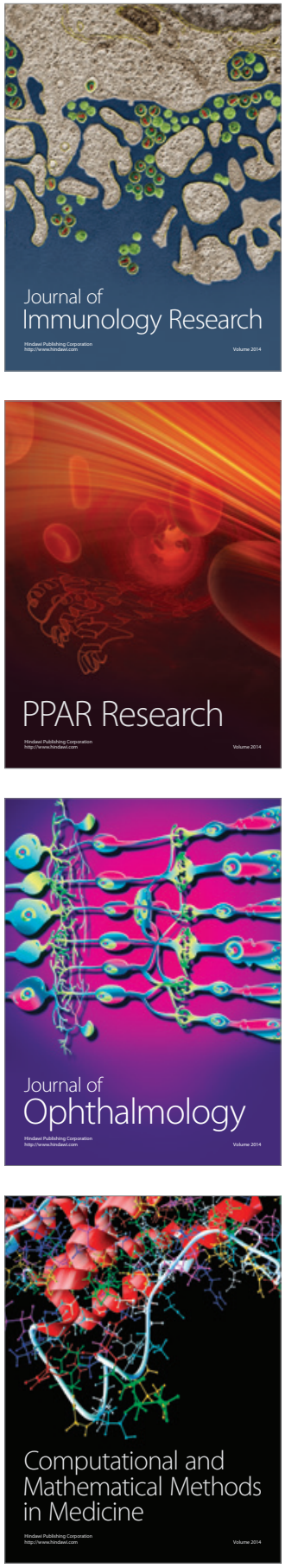

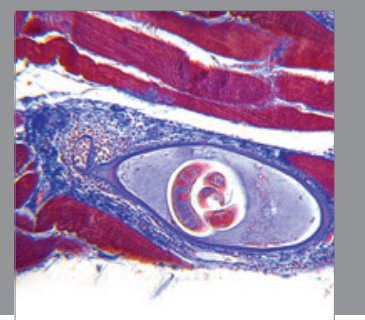

Gastroenterology

Research and Practice
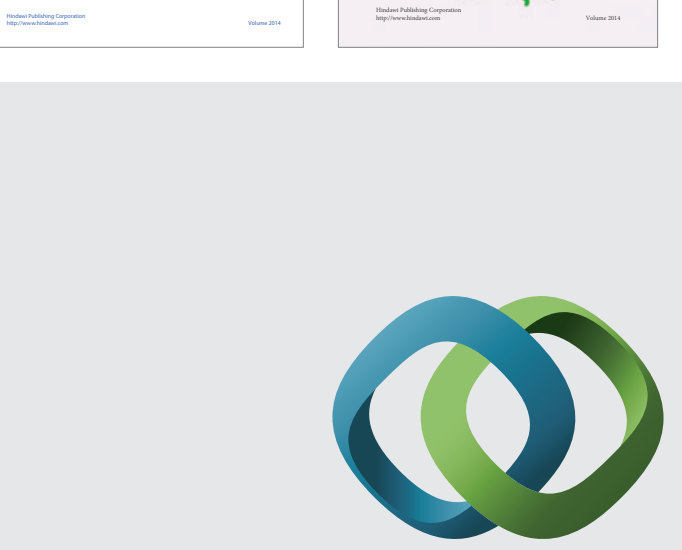

\section{Hindawi}

Submit your manuscripts at

http://www.hindawi.com
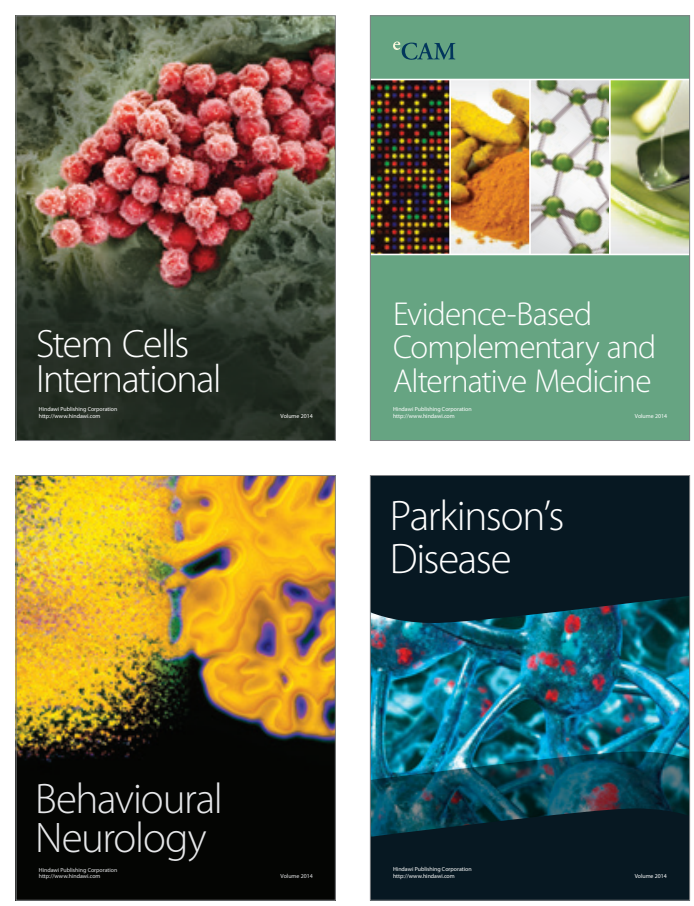

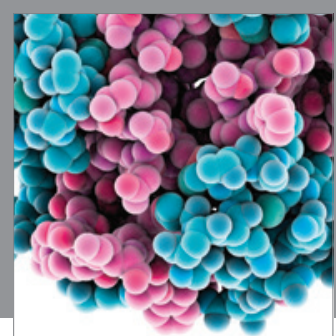

Journal of
Diabetes Research

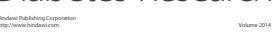

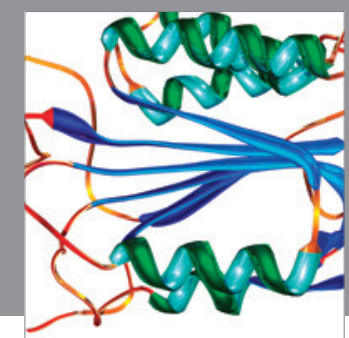

Disease Markers
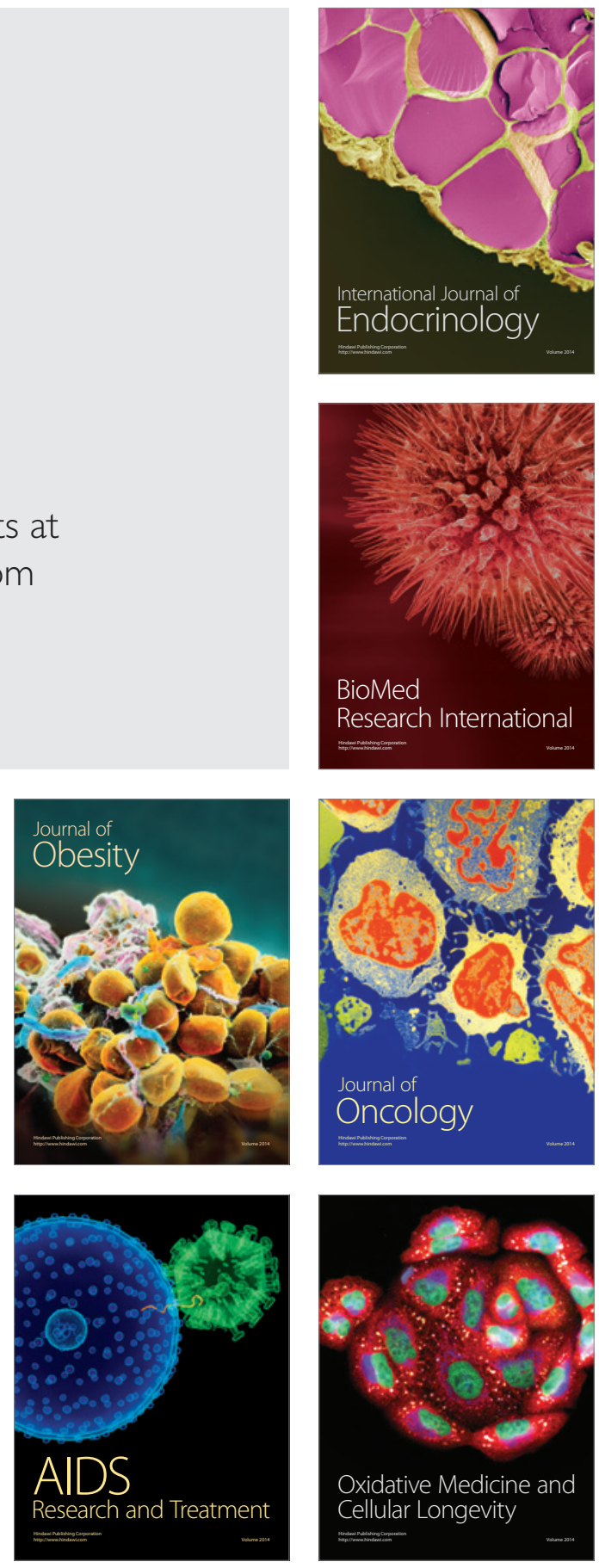